\title{
Hydrogen refuelling station with integrated metal hydride compressor: Layout features and experience of three-year operation
}

\author{
Mykhaylo Lototskyy ${ }^{a, *}$, Moegamat Wafeeq Davids ${ }^{a}$, Dana Swanepoel ${ }^{b}$, \\ Gerhard Louw ${ }^{b}$, Yeugeniy Klochko ${ }^{a}$, Fahmida Smith ${ }^{c}$, Fatema Haji ${ }^{c}$, \\ Ivan Tolj $^{a, d}{ }^{\text {, Stanford Chidziva }}{ }^{a}$, Sivakumar Pasupathi ${ }^{a}$, \\ Vladimir Linkov ${ }^{a}$ \\ ${ }^{a}$ HySA Systems Competence Centre, South African Institute for Advanced Materials Chemistry (SAIAMC), \\ University of the Western Cape, Bellville, 7535, South Africa \\ ${ }^{\mathrm{b}}$ TF DESIGN (Pty) Ltd., Stellenbosch, 7600, South Africa \\ c Impala Platinum Holdings Ltd., Illovo, 2196, South Africa \\ d University of Split, Faculty of Mechanical Engineering and Naval Architecture, Department of Thermodynamics and \\ Heat Engines, Split, 21000, Croatia
}

\section{A R T I C L E I N F O}

Article history:

Received 1 February 2019

Received in revised form

5 May 2019

Accepted 14 May 2019

Available online $\mathrm{xxx}$

Keywords:

Hydrogen refuelling

Industrial customers

Metal hydride compressor

\begin{abstract}
A B S T R A C T
Hydrogen compression is a main contributor in the capital and operation costs of the $\mathrm{H}_{2}$ refuelling infrastructure. The use of metal hydrides $(\mathrm{MH})$ for thermally-driven $\mathrm{H}_{2}$ compression can provide efficient solution to mitigate this challenge. $\mathrm{MH}$ compressors are particularly promising for industrial customers who possess necessary infrastructure including pipeline $\mathrm{H}_{2}$, sources of low-grade heat, etc.

Here we present the details about layout of the $\mathrm{H}_{2}$ refuelling station and its operation at Impala Platinum refineries in Springs, South Africa, since its start-up in September 2015. The station provides $\mathrm{H}_{2}$ dispensing at the pressure up to 185 bar and uses pipeline $\mathrm{H}_{2}$ ( $\mathrm{P}=50-60$ bar) available at the customer site. $\mathrm{H}_{2}$ compression to $\mathrm{P}=200$ bar with productivity up to $13 \mathrm{Nm}^{3} / \mathrm{h}$ is provided by the integrated 1-stage $\mathrm{MH} \mathrm{H}_{2}$ compressor which uses steam $\left(\mathrm{T} \sim 140^{\circ} \mathrm{C}\right)$ for the heating and circulating water $\left(\mathrm{T} \sim 20^{\circ} \mathrm{C}\right)$ for the cooling; both steam and water are also available from the customer infrastructure. The station also includes $\mathrm{H}_{2}$ dispenser, buffer tank (standard gas cylinder pack), and control block on the basis of Siemens Program Logic Controller (PLC) which provides fully automated system operation. Switching $\mathrm{H}_{2}$ and steam/water flows is carried out with the help of remotely controlled, pneumatically actuated valves and auxiliary check valves. Additionally, at $\mathrm{P}=200$ bar the control block switches the system into standby mode when $\mathrm{MH}$ compression modules are cooled down and their gas manifolds are connected to the $\mathrm{H}_{2}$ supply line. The $\mathrm{H}_{2}$ dispensing is independent on the compressor operation and takes from 6 to $15 \mathrm{~min}$. The refuelling station complies with South African safety regulations for operation in a fire and explosion hazardous environment.
\end{abstract}

๑ 2019 Hydrogen Energy Publications LLC. Published by Elsevier Ltd. All rights reserved.

\footnotetext{
* Corresponding author.

E-mail address: mlototskyy@uwc.ac.za (M. Lototskyy). 


\section{Introduction}

Very high capital and operating costs of hydrogen refuelling infrastructure significantly hinder market adoption of fuel cell vehicles. The contribution of hydrogen refuelling stations was estimated as $\sim 50 \%$ of the cost of hydrogen fuel at dispenser to be between USD 13 and 15 per $1 \mathrm{~kg} \mathrm{H}_{2}$ (California, 2017) [1-3]. Of the total investments in a less expensive $\mathrm{H}_{2}$ refuelling station (150 kg $\mathrm{H}_{2}$ /day, truck-delivered $\mathrm{H}_{2}$; USD 600000 , Shanghai, 2007), about $60 \%$ relates to the infrastructure providing hydrogen storage, compression and purification [4]. Additional capital costs (10-11\%) are necessary to provide hydrogen pre-cooling [1,2,5].

Hydrogen compression is a major contributor to the capital costs (48\%) and maintenance hours (24\%) of the $\mathrm{H}_{2}$ refuelling stations [5]. Conventional use of mechanical $\mathrm{H}_{2}$ compressors is associated with safety and reliability issues mainly related to the operation of moving parts and their seals under high hydrogen pressures (up to 400 and 900 bar for $\mathrm{H}_{2}$ dispensing pressures of 350 and 700 bar, respectively). Relatively high energy consumption for $\mathrm{H}_{2}$ compression, $>15 \%$ of the lower $\mathrm{H}_{2}$ heating value [6], results in high electricity costs which, together with the maintenance costs, are the main contributors to the operating costs of the hydrogen compression component of the refuelling infrastructure.

Metal hydride hydrogen compressors (MHHC), which use reversible thermally driven interaction of hydride forming metals and alloys with hydrogen gas are promising alternative to conventional mechanical compressors of hydrogen. The MHHC have a number of advantages including practically unlimited discharge pressure (up to several kilobars), scalability (from $\mathrm{x} \mathrm{L} / \mathrm{h}$ to $\mathrm{x} \mathrm{m}^{3} / \mathrm{h} \mathrm{H}_{2}$ ), modular design, simplicity in service and repair, high purity of the released $\mathrm{H}_{2}$. Except for some gas-distribution components (e.g. check valves), there are no moving parts (pistons, membranes) in the MHHC that results in the simplification of the design and the increase of operation reliability [7-10]. As compared to novel method of electrochemical hydrogen compression having similar advantages [11], MHHC do not require complicated sealing of $\mathrm{H}_{2}$ compressing stack resulting in higher safety and reliability as respect to leaks at high $\mathrm{H}_{2}$ pressures. MHHC also allow to utilise waste heat instead of electricity for $\mathrm{H}_{2}$ compression and thus are very beneficial for industrial customers who have this resource in their possession [7-9].

In Refs. [12,13] we reported about development of metal hydride $(\mathrm{MH})$ extension tank for fuel cell powered forklift, along with $\mathrm{H}_{2}$ refuelling station with integrated MHHC. Due to presence of the $\mathrm{MH}$ component in the on-board hydrogen storage system, the $\mathrm{H}_{2}$ dispensing pressure could be lowered from 350 to $\leq 185$ bar without decrease of the useable hydrogen storage capacity $(>1.8 \mathrm{~kg})$ which was reached in a reasonable refuelling time (6-15 $\mathrm{min})$. The above-mentioned publications were mainly focused on the layout of the onboard hydrogen storage system and performances of the forklift, and the features of the refuelling station (including the ones previously reported in Refs. $[8,9]$ ) were considered only briefly.
Here we present the details about layout of the $\mathrm{H}_{2}$ refuelling station and its operation at Impala Platinum refineries in Springs, South Africa, since its start-up in September 2015.

\section{Features}

\section{General layout and specification}

The hydrogen refuelling station is intended for the refuelling of fuel cell forklifts at Impala Platinum Refineries at $\mathrm{H}_{2}$ dispensing pressure up to 185 bar and ambient temperature.

Figs. 1 and 2 show the general layout and the images of the hydrogen refuelling station. The station includes the following components:

- Hydrogen dispenser (2) integrated with thermally driven metal hydride hydrogen compressor (1);

- Buffer hydrogen storage/gas cylinder pack (3);

- Control block (4);

- A console (5) holding hydrogen refuelling nozzle (5a), connector for water removal (5b), ejector for water removal (5c) and earth clamp;

- Hydrogen venting pipeline (6).

The refuelling station consumes the following services supplied by the customer (see Fig. 2, right):

- Low pressure hydrogen (50-60 bar, 99.99\% purity, <1 ppm $\mathrm{CO}$ and $\mathrm{CO}_{2}$ ), consumption up to $15 \mathrm{Nm}^{3} / \mathrm{h}$;

- Low grade steam $\left(130-180^{\circ} \mathrm{C}\right)$, consumption up to $33 \mathrm{~kg} / \mathrm{h}$;

- Circulating cooling water (supply at $\mathrm{T} \leq 30^{\circ} \mathrm{C}$ and return), consumption up to $15 \mathrm{~kg} / \mathrm{min}$;

- Instrument air (5.5-7.5 bar), average consumption below 1 $\mathrm{NL} / \mathrm{min}$, peak consumption up to $55.5 \mathrm{NL} / \mathrm{min}$ for not longer than $15 \mathrm{~min}$;

- Nitrogen (for the purging $\mathrm{H}_{2}$ systems before and after service works);

- Electric power (525 or 230 VAC, single phase), consumption up to $2000 \mathrm{~W}$.

\section{Components}

A simplified gas piping diagram of the refuelling station is shown in Fig. 3.

The one-stage MH compressor (1) comprises of two compression modules (Module 1, Module 2) each of which includes three $\mathrm{MH}$ containers (1.1.1..1.1.3 and 1.2.1...1.2.3) connected in parallel to gas manifolds, pressure sensors (1.3...1.6), manual shut-off valves ( $\mathrm{H}_{2}$ input, 1.7; $\mathrm{H}_{2}$ output, 1.17), check valves $(1.8,1.9,1.14,1.15)$, remotely controlled pneumatically actuated shut-off valves $(1.10 . .1 .13,1.16)$, safety relief valve (1.18), $\mathrm{H}_{2}$ coolers $(1.19,1.20)$.

The $\mathrm{H}_{2}$ dispenser (2) is connected to the output of the compressor in parallel to the gas buffer (3). The main parts of the dispenser (2) include remotely controlled pneumatically 


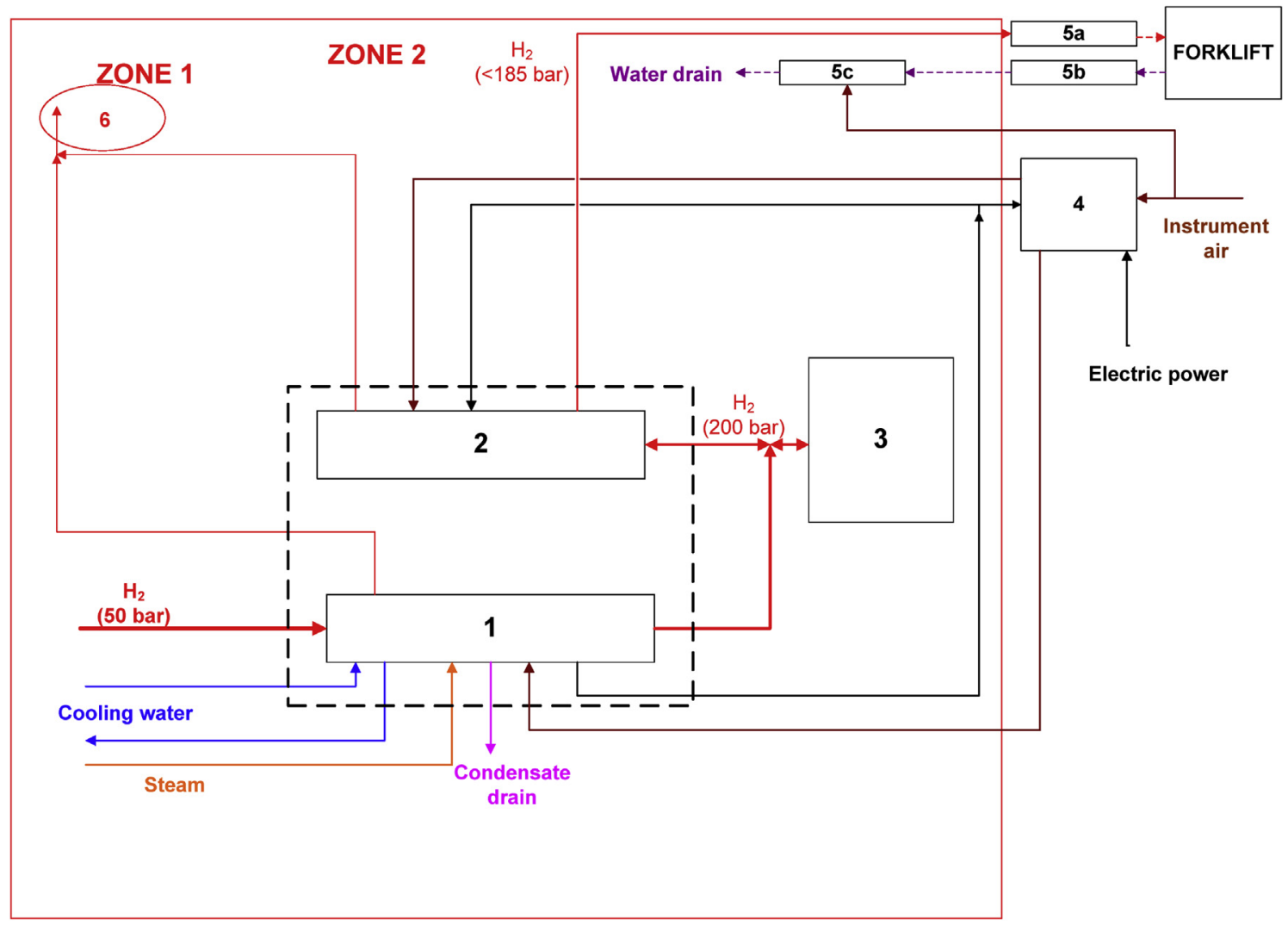

Fig. 1 - General layout of the hydrogen refuelling station.

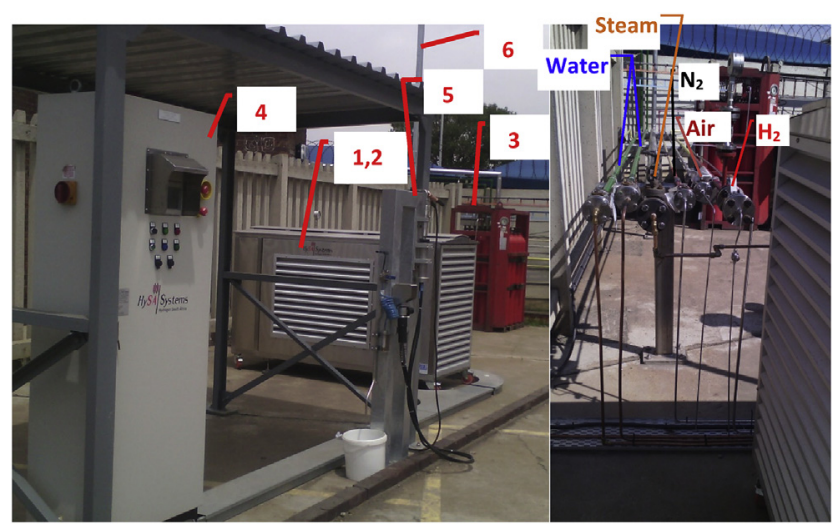

Fig. 2 - Images of the hydrogen refuelling station including connections of service pipelines (right). Labelling of the components corresponds to Fig. 1.

actuated shut-off valves (2.1...2.3), check valves (2.4, 2.5), $\mathrm{H}_{2}$ mass flow meter (2.6), pressure sensor (2.7), remotely controlled pressure regulator (2.8). The dispenser is also connected to the $\mathrm{H}_{2}$ supply and vent pipelines of the refuelling nozzle (5a) and $\mathrm{H}_{2}$ venting pipeline (6).

The control block (4) provides periodic heating and cooling of the compression modules $(1.1,1.2)$, as well as switching gas flows during operation of the $\mathrm{MH}$ compressor by the opening/ closing the valves $1.10 \ldots 1.13,1.16$. It also provides operation of the dispenser (2) by the opening/closing the valves $2.1 \ldots 2.3$ and setting the pressure regulator 2.8 .

More detailed description of the components is given below.

\section{MH compressor}

For the $\mathrm{H}_{2}$ compression, we used a C14-AB - -type $\mathrm{Ti}_{0.65}$ $\mathrm{Zr}_{0.35}(\mathrm{Mn}, \mathrm{Cr}, \mathrm{Fe}, \mathrm{Ni})_{2+\mathrm{x}}$ hydride forming alloy. As it can be seen from Fig. 4, this material allows $\mathrm{H}_{2}$ compression from $\mathrm{P}_{\mathrm{L}}$ $=50$ bar to $P_{H}=200$ bar in the temperature range $25-130{ }^{\circ} \mathrm{C}$ with a cycle productivity about $100 \mathrm{NL} \mathrm{H}_{2} / \mathrm{kg}$.

More details about characterisation of the used $\mathrm{MH}$ material are presented in Ref. [9] and [14] (sample \#5).

The material was loaded in six $\mathrm{MH}$ containers for $\mathrm{H}_{2}$ compression.

The MH container is made of stainless steel (seamless pipe ASTM A312 GR.TP 316 SHED 80S for the pressure vessel body) and has the following features:

- Water cooling to $\mathrm{T}_{\mathrm{L}} \sim 15-20{ }^{\circ} \mathrm{C}$;

- Direct steam heating to $\mathrm{T}_{\mathrm{H}} \sim 120-140{ }^{\circ} \mathrm{C}$;

- Internal "tube in tube" heat exchanger (stainless steel core tube with extruded aluminium fins);

- External heating/cooling jacket.

Each container $(\varnothing 101.6 \times 1619 \mathrm{~mm}$, void volume $4.755 \mathrm{~L}$, design pressure/temperature 200 bar/ $-50 \ldots+200{ }^{\circ} \mathrm{C}$ ) was loaded with $14.6 \mathrm{~kg}$ of $\mathrm{MH}$ material including $13 \mathrm{~kg}$ of the $\mathrm{AB}_{2^{-}}$ 


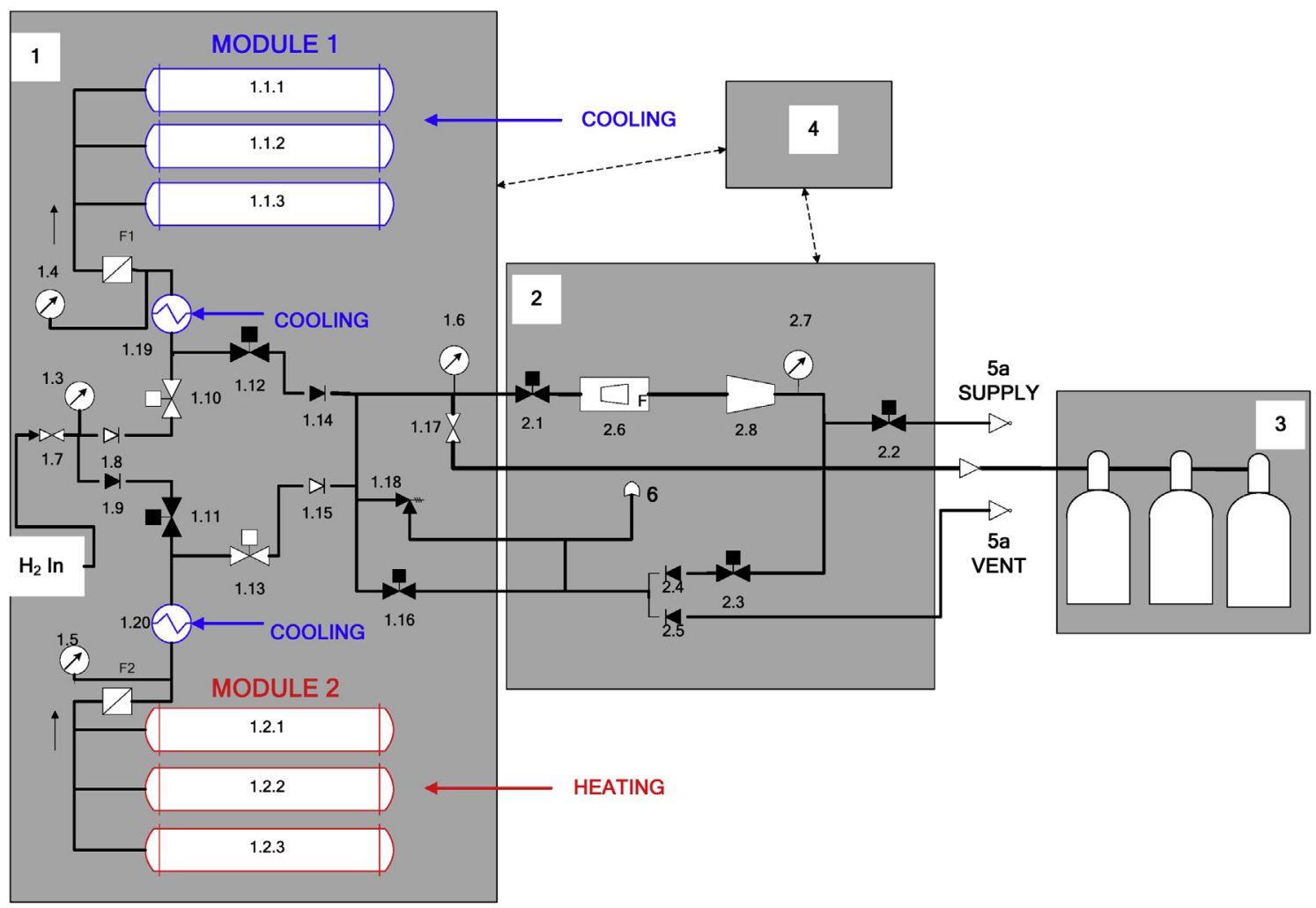

Fig. 3 - Simplified gas piping diagram of the refuelling station. Numbering of the main components (1-6) corresponds to Fig. 1 and 2. To illustrate the operation of the MH compressor, the closed valves are shown as filled and the opened ones as empty.

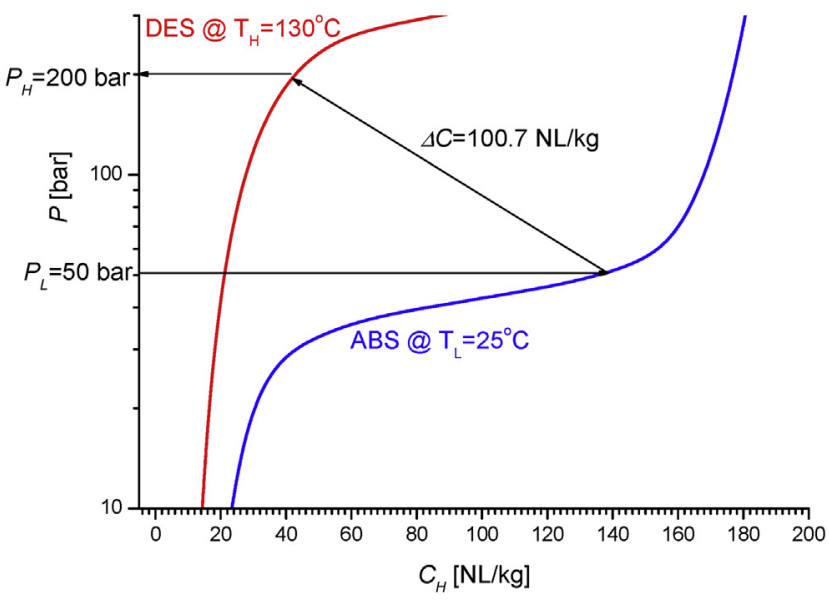

Fig. 4 - Pressure - composition isotherms for $\mathrm{H}_{2}$ absorption at the low temperature $\left(\mathrm{T}_{\mathrm{L}}\right)$ and $\mathrm{H}_{2}$ desorption at the high temperature $\left(\mathrm{T}_{\mathrm{H}}\right)$ for the $\mathrm{AB}_{2}$-type $\mathrm{MH}$ material used in the $\mathrm{H}_{2}$ compressor.

type alloy described above mixed with $1.45 \mathrm{~kg}$ of $\mathrm{AB}_{5}$-type hydrogen storage alloy $\left(\mathrm{La}_{0}{ }_{8} \mathrm{Ce}_{0 \cdot 2} \mathrm{Ni}_{5}\right)$ and $0.15 \mathrm{~kg}$ of expanded natural graphite (ENG) powder. According to our solution [15], the additives were used for facilitation of the activation $\left(A_{5}\right)$ as well as for the improvement of heat transfer in the $\mathrm{MH}$ bed, in combination with minimizing stresses on the container's wall due to swelling of the bed ${ }^{1}$ in the course of hydrogenation (ENG).

More details about design of the $\mathrm{MH}$ container and its performances during $\mathrm{H}_{2}$ compression are presented in Ref. [9].

The $\mathrm{MH}$ compressor maintains high hydrogen pressure (195-200 bar) in the buffer storage cylinder pack (3 in Figs. $1-3)$ by the compression of low pressure (50-60 bar) hydrogen supplied from the input pipeline $\left(\mathrm{H}_{2} \mathrm{In}\right.$ in Fig. 3). The $\mathrm{H}_{2}$ compression is thermally driven and does not consume electric power. It is provided by the periodic (i) cooling of $\mathrm{MH}$ material in $\mathrm{MH}$ containers assembled in two compression modules accompanied by low pressure hydrogen absorption therein and (ii) heating of the $\mathrm{MH}$ material in the $\mathrm{MH}$ containers accompanied by high pressure hydrogen desorption therefrom.

The main gas piping elements of $\mathrm{MH}$ compressor include (Figs. 3 and 5):

- Hydrogen input pipeline $\left(\mathrm{H}_{2} \mathrm{In}\right)$;

- Hydrogen input (1.7) and output (1.17) manual valves equipped with position sensors;

- Pressure sensors installed at hydrogen input (1.3), gas manifolds of the containers $(1.4,1.5)$, and hydrogen output (1.6);

\footnotetext{
${ }^{1}$ Filling density $~ 55 \%$ of the material's real density in the hydrogenated state.
} 


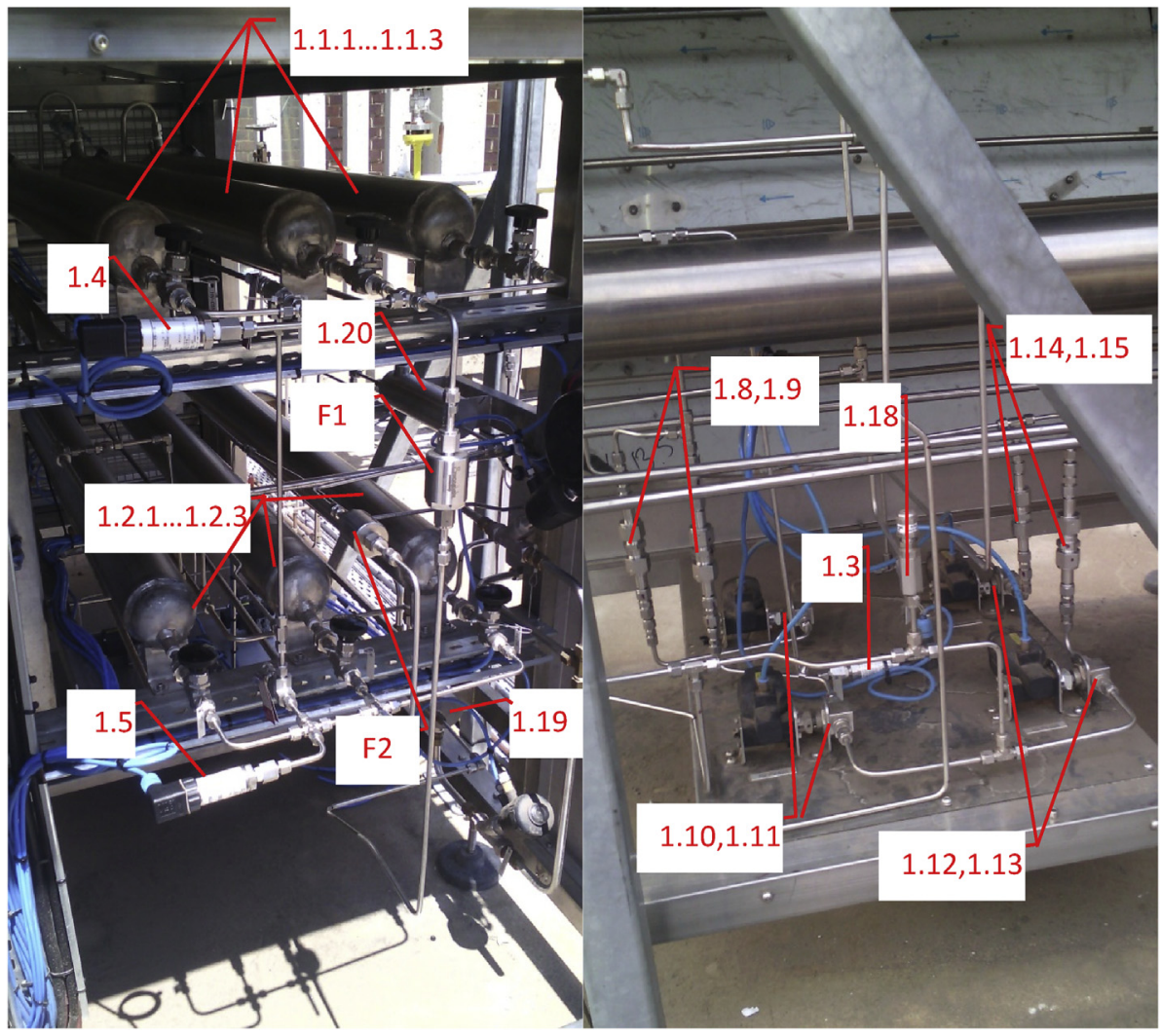

Fig. 5 - Views of the gas piping of the MH compressor. Labelling of the components corresponds to Fig. 3.

- Arrangement of pneumatically actuated (1.10...1.13) and check $(1.8,1.9,1.14,1.15)$ valves periodically switching hydrogen flows between gas manifolds of the compression modules and input/output $\mathrm{H}_{2}$ pipelines;

- Six MH containers (1.1.1...1.1.3 and 1.2.1..1.2.3) equipped with $0.5 \mu \mathrm{m}$ sintered metal inline filters and manual shutoff valves (see Fig. 5, left);

- Fine inline filters (F1, F2; $0.003 \mu \mathrm{m})$ installed between gas manifolds of the compression modules and other gas systems of the compressor;

- Coolers $(1.19,1.20)$ for lowering temperature of the high pressure hydrogen delivered from the heated $\mathrm{MH}$ containers;

- Safety relief valve (1.18; set cracking pressure 210 bar);

- Pneumatically actuated valve (1.16), for the connection to vent pipeline (6) when regeneration of the $\mathrm{MH}$ material is necessary;

- Manual valves (not shown) for purging the gas systems with nitrogen (for installation and service works only).

The cooling of the $\mathrm{MH}$ containers/compression modules is provided by running water, and the heating - by steam. Fig. 6 shows the steam and water piping diagram in the heating/ cooling system.

The steam and water piping elements of the $\mathrm{MH}$ compressor include:
- Heating/cooling circuits of Module 1 and Module 2 formed by the parallel connection of the heat exchangers of $\mathrm{MH}$ containers. Each $\mathrm{MH}$ container has an internal heat exchanger and an external heating/cooling jacket connected in sequence. The internal heat exchangers are connected to steam/water manifolds at the top of the module/container's assembly (TMF1, TMF2) while the external heating/cooling jackets - to the manifolds (BMF1, BMF2) at the bottom. The opposite direction of the heating (steam) and cooling (water) fluids results in faster system response when switching from cooling to heating and vice versa.

- Connecting pipelines for the supply (Water supply) and return (Water out) of the cooling water.

- Connecting pipelines for the Steam supply and Condensate drain.

- Pneumatically actuated valves for water supply to Module 1 (PV1) and Module 2 (PV2).

- Pneumatically actuated valves for water drain from Module 1 (PV3) and Module 2 (PV4).

- Heat exchangers of the coolers of hydrogen delivered from Module 1 (HE1) and Module 2 (HE2).

- Pneumatically actuated valves for steam supply to Module 1 (PV5) and Module 2 (PV6).

- Pneumatically actuated valves for condensate removal from Module 1 (PV7) and Module 2 (PV8). 


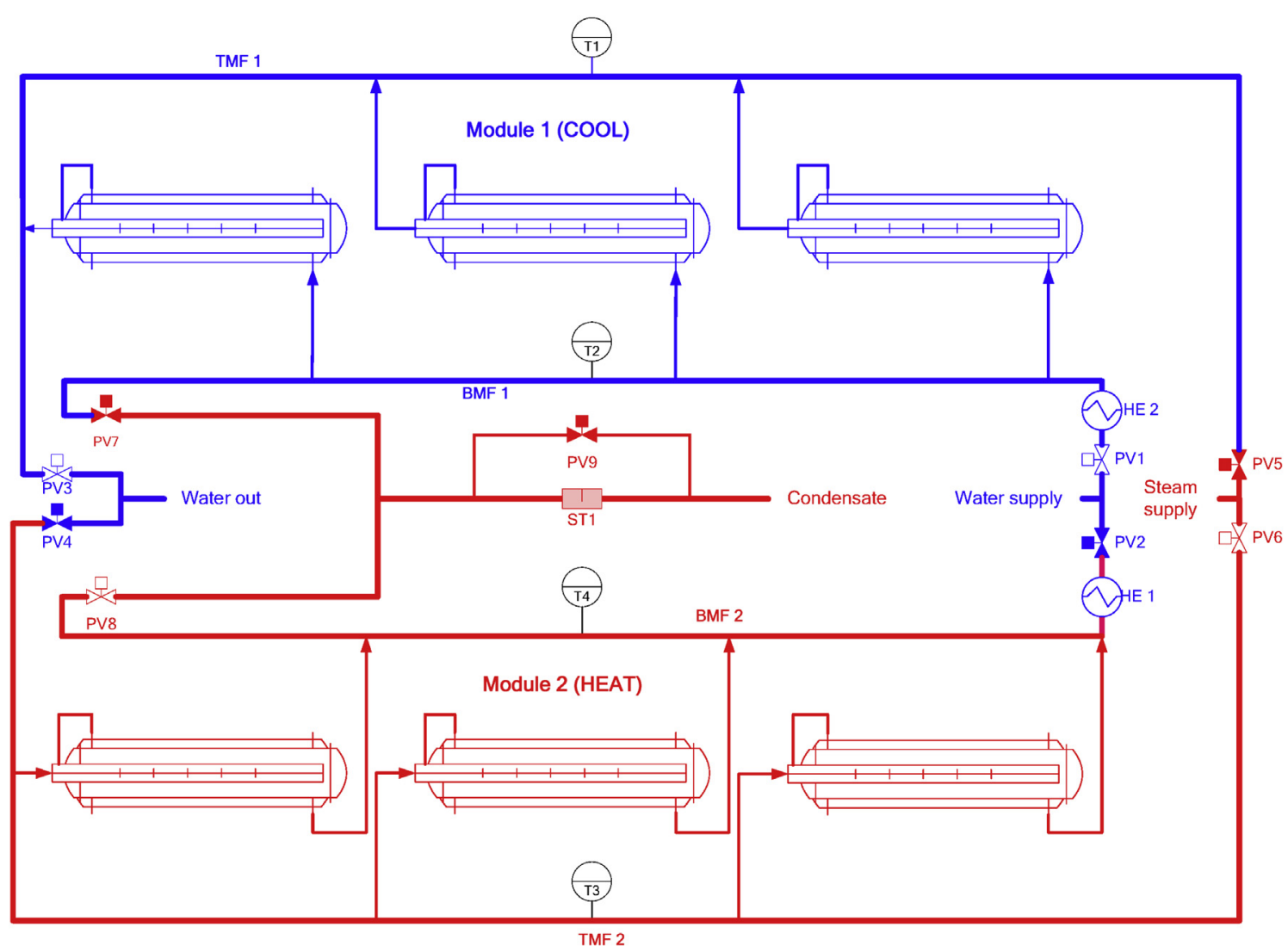

Fig. 6 - Steam and water piping diagram of the MH compressor. The closed valves are shown as filled and the opened ones - as empty.

- Top (T1) and bottom (T2) temperature sensors of Module 1 heating/cooling circuit.

- Top (T3) and bottom (T4) temperature sensors of Module 2 heating/cooling circuit.

- Steam trap (ST1) with pneumatically actuated bypass valve (PV9).

The operation of the compressor is provided by the control block by opening and closing gas $(1.10 \ldots 1.13,1.16)$ and steam/ water (PV1...PV9) valves thus providing one of the operation modes listed in Table 1 . The compressor is automatically switched from the $\mathrm{H}_{2}$ compression to the standby mode when the output pressure exceeds 200 bar. In doing so, both modules are cooled down to be charged with $\mathrm{H}_{2}$. The $\mathrm{H}_{2}$ compression mode is activated again when the output pressure drops below 195 bar.

The regeneration mode provides recovery of hydrogen sorption performance of the material by a long heating-up the $\mathrm{MH}$ containers with simultaneous release of hydrogen and residual gases into venting line. The regeneration is followed by the charge of the cooled $\mathrm{MH}$ containers with $\mathrm{H}_{2}$, similar to the standby mode.

\section{Dispenser}

The dispenser (Figs. 3 and 7) provides $\mathrm{H}_{2}$ supply to the refuelling nozzle connected to the forklift hydrogen receptacle and venting of the pressurised hydrogen after completion of the refuelling.

The main elements of the dispenser include:

- High pressure hydrogen supply valve (2.1);

- Hydrogen output valve (2.2);

- Hydrogen venting valve (2.3);

- Hydrogen venting check valves $(2.4,2.5)$;

- Flow meter (2.6);

- Dispensing pressure sensor (2.7);

- Electro-pneumatically actuated pressure regulator (2.8).

After connection of the refuelling nozzle to hydrogen receptacle of the forklift fuel cell power module and sending the command by the operator from the control block, the dispenser provides safe filling of the forklift hydrogen storage system with the pressurised hydrogen. The filling stages (see Fig. 8) include:

- Delay of the beginning of pressure increase after sending the command to start refuelling (Start Delay, 0.5-1 min);

- Smooth increase of $\mathrm{H}_{2}$ dispensing pressure setpoint to the maximum value of (185 bar) during Ramp Time, 5-15 min;

- Maintaining of the maximum $\mathrm{H}_{2}$ dispensing pressure during Settling Time, 5-10 min; 

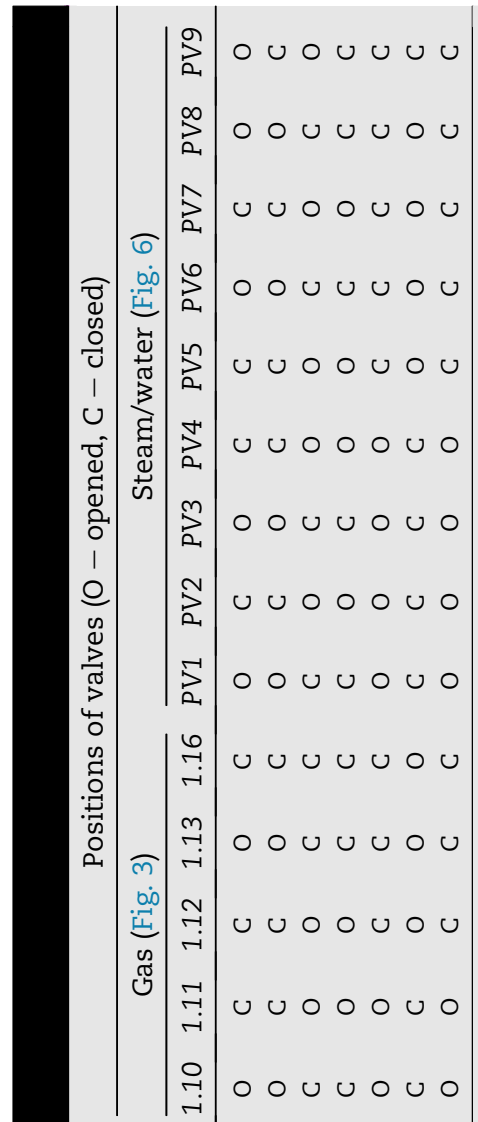

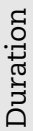

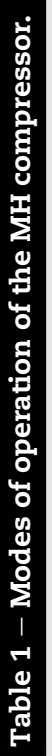

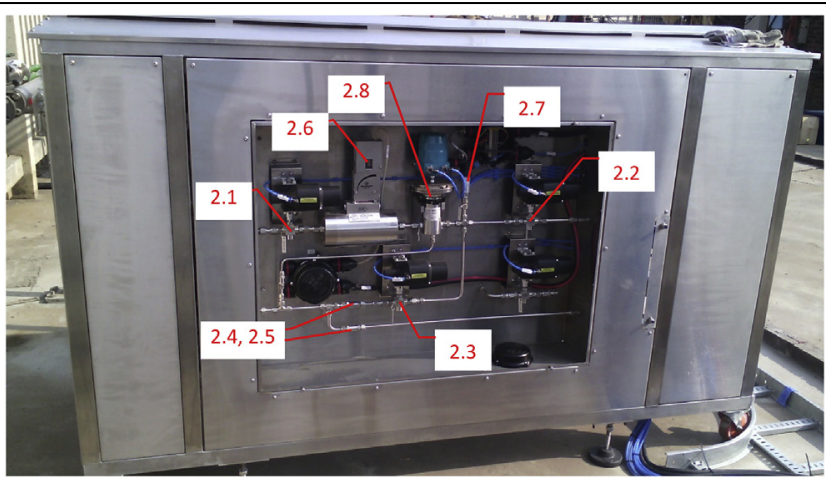

Fig. 7 - View of the dispenser section. Labelling of the components corresponds to Fig. 3.

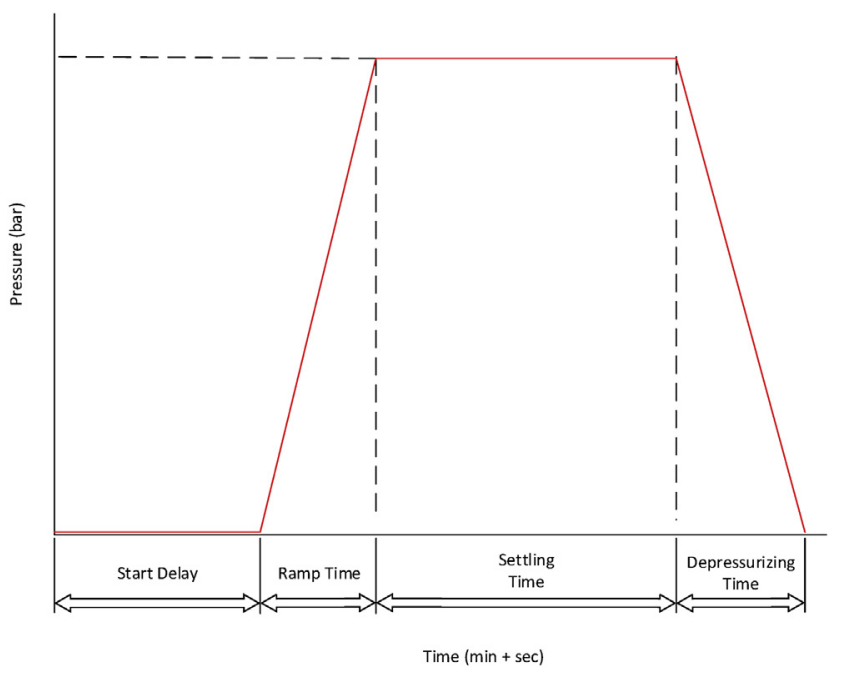

Fig. 8 - Operation cyclogram of the hydrogen dispenser.

- Smooth decrease of $\mathrm{H}_{2}$ dispensing pressure from the maximum value to zero during Depressurizing Time, 3-5 $\min$.

Due to relatively slow pressure ramping, 5-15 $\mathrm{min}$, hydrogen supplied to the storage system on-board the forklift is not overheated: maximum temperature of $\sim 55{ }^{\circ} \mathrm{C}$ was observed in the $\mathrm{MH}$ extension tank during the first 5-8 min of the refuelling cycle [13]. This eliminates requirement for deep cooling of the dispensed $\mathrm{H}_{2}$ thus resulting in a simpler design and lower costs of the developed refuelling station.

Buffer

The necessary amount of the compressed $\mathrm{H}_{2}$ is provided by the buffer storage ( 3 in Figs. 1 and 2), a standard pack frame assembly of 18 gas cylinders (supplier Air Products South Africa (Pty) Ltd), with the total internal volume of $900 \mathrm{~L}$ and hydrogen storage pressure up to 200 bar. The buffer is connected to both hydrogen dispenser and $\mathrm{MH}$ hydrogen compressor; the latter maintains the maximum $\mathrm{H}_{2}$ pressure (195-200 bar) in the buffer during the operation of the hydrogen refuelling station. 


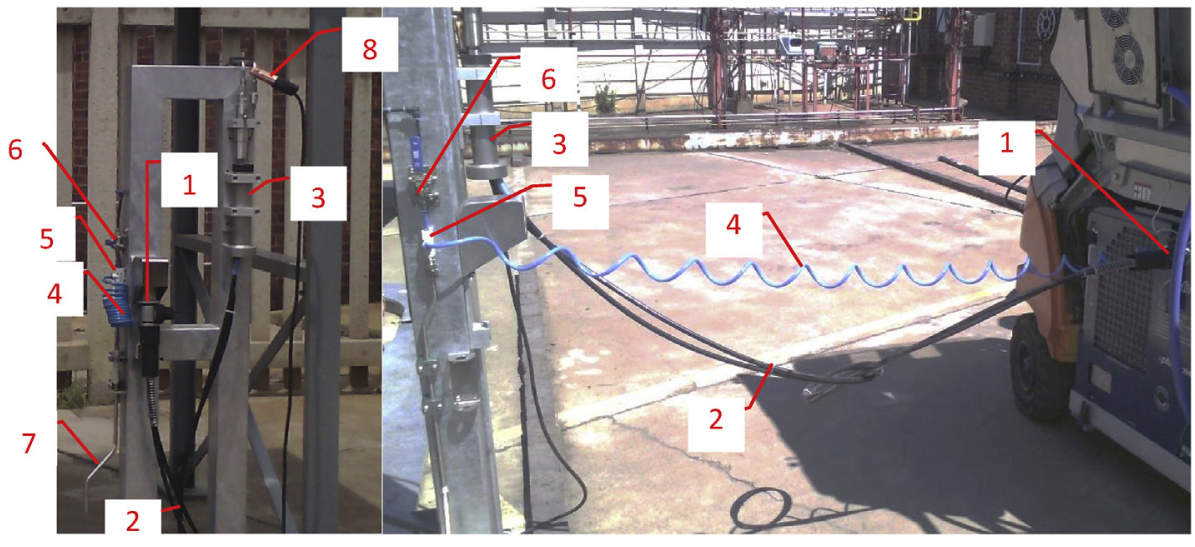

Fig. 9 - Parts of the refuelling console.

\section{Refuelling console}

The refuelling console (5 in Fig. 2) carries the elements necessary for the safe forklift refuelling. These elements are shown in Fig. 9.

The refuelling of the forklift is provided by the TK-16H2 refuelling nozzle (1; maximum dispensing pressure 250 bar) to be connected to hydrogen receptacle of the forklift fuel cell power module (see Fig. 9, right). The nozzle is equipped with two flexible hoses (2), one for $\mathrm{H}_{2}$ supply and another for the safe $\mathrm{H}_{2}$ vent when disconnecting the nozzle from the receptacle. Both hoses are connected to TSA-1 H2 breakaway coupling (3) installed on the console to avoid abrupt release of high pressure hydrogen if the forklift will accidently move during the refuelling. The parts 1-3 were supplied by WEH $\mathrm{GmbH}$, Germany. Further connection of the hydrogen supply and venting lines to hydrogen dispenser is provided by $3 / 8^{\prime \prime}$ OD 316 stainless steel pipelines.

As a rule, the refuelling has to be accompanied by the removal of water formed during the operation of the forklift fuel cell power module. To perform this operation, the system is equipped with a flexible hose for water removal (4) with a quick coupling which, when water tank of the forklift power module has to be emptied, is connected to the dewatering nipple of the forklift power module. From the other side, the hose (4) is connected to the ejector (5). The ejector (5) is also connected to the compressed air line, via manual shut-off valve (6); the water is drained to pipeline (7).

To avoid appearance of electric sparks, the console also has an earth clamp (8) which is connected to a metal part of the forklift before the refuelling.

\section{Control block}

The control block (4 in Figs. 1 and 2) provides fully automated operation of the refuelling system with minimal interventions from the operator via human machine interface (HMI) using Siemens programmable logic controller (PLC).

The control block is assembled in a frame (Fig. 10 left) and is connected to (i) electric supply cable, (ii) source of compressed air, (iii) electric and (iv) pneumatic systems of hydrogen dispenser and compressor unit. Depending on the available electric supply, the control block can be powered from industrial (525 V) or common (230 V) single-phase AC network $(10 \mathrm{~A}, 50 \mathrm{~Hz}$ ); the corresponding change-over switch is located inside the compartment. Electric cable connecting the block with the hydrogen dispenser and compressor unit provides the powering (24 VDC) of sensors located in the latter and receives the corresponding sensor signals via Ex-proof barriers while the actuation of valves and pressure controller is provided by pneumatic pipelines.

Switching the system on is provided by an isolator switch located on the top left of the block compartment (1; Fig. 10 (left)). All other controls and indicators are located in the front door, including emergency stops of the whole system (2) and the dispenser (3), HMI touch-screen (4), and panel switches, indicators and ports (5); see also Fig. 10 (right). The control panel elements include: Compressor Off/On selector switch; Compressor Active indicator; Alarm Active indicator; Start H2 Filling push button; H2 Filling Busy indicator; H2 Filling Complete indicator; USB Data Logging port; and Ethernet port.

The control block provides:

- Fully automated operation of the MH compressor (see Table 1) including switching between operation and standby modes, when the selector switch Compressor Off/ On is on;

- $\mathrm{H}_{2}$ refuelling independent on the operation of the $\mathrm{MH}$ compressor, after pushing Start H2 Filling button;

- Visual monitoring, data logging and control of system parameters including switching the compressor to regeneration mode and manual operation of all system components, via HMI interface;

- Change of the operation setponts via HMI interface including:

- Duration of stages for the different modes of the operation of MH compressor (Table 1);

- Maximum dispensing pressure and duration of stages for $\mathrm{H}_{2}$ refuelling (Fig. 8);

- High and low pressure limits for the switching between the operation and standby modes;

- Other system parameters including pressure differences when opening valves 1.10...1.13 (Fig. 3), as well as alarm setpoints. 


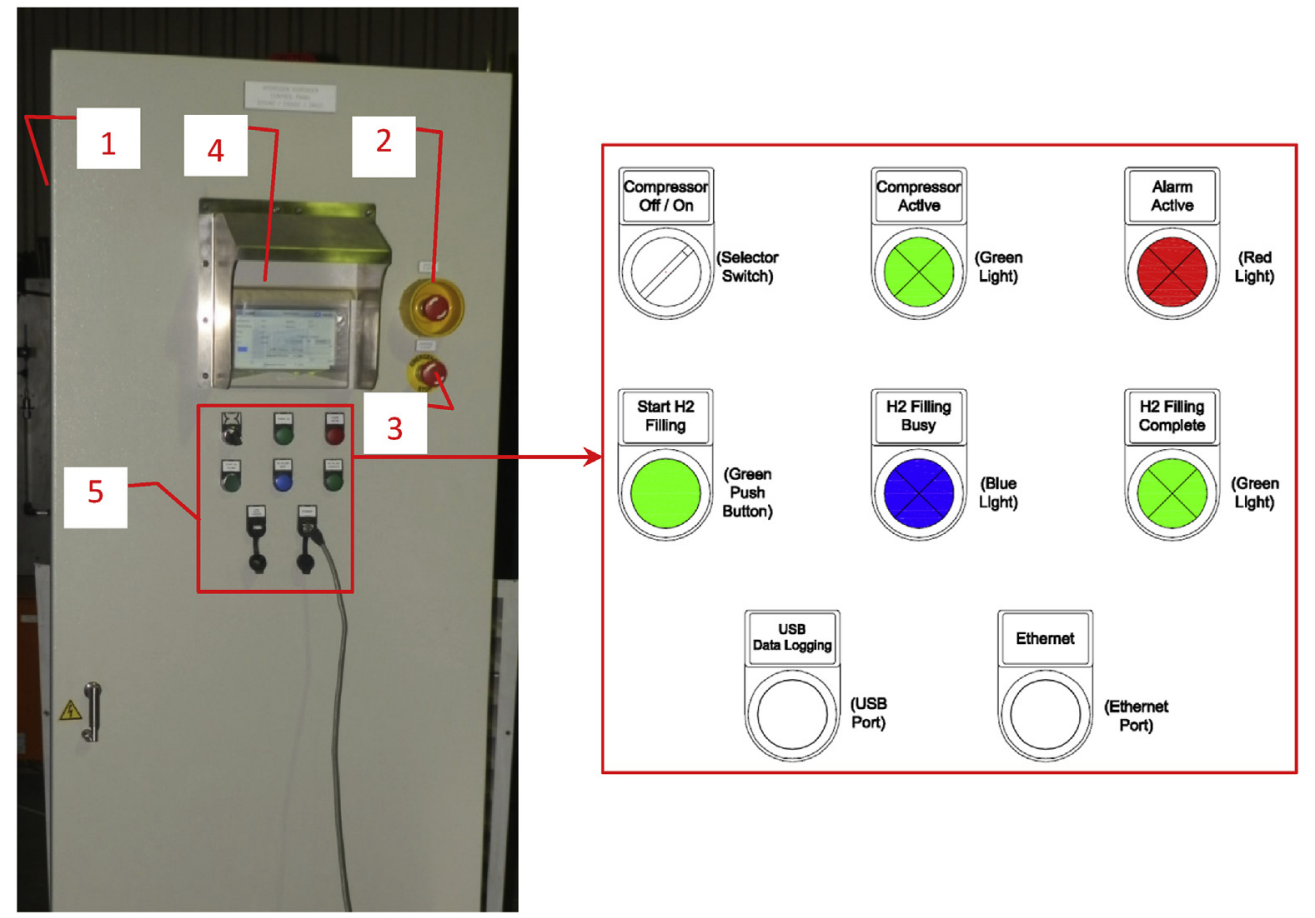

Fig. 10 - Front view of the control block (left) and panel door layout (right).

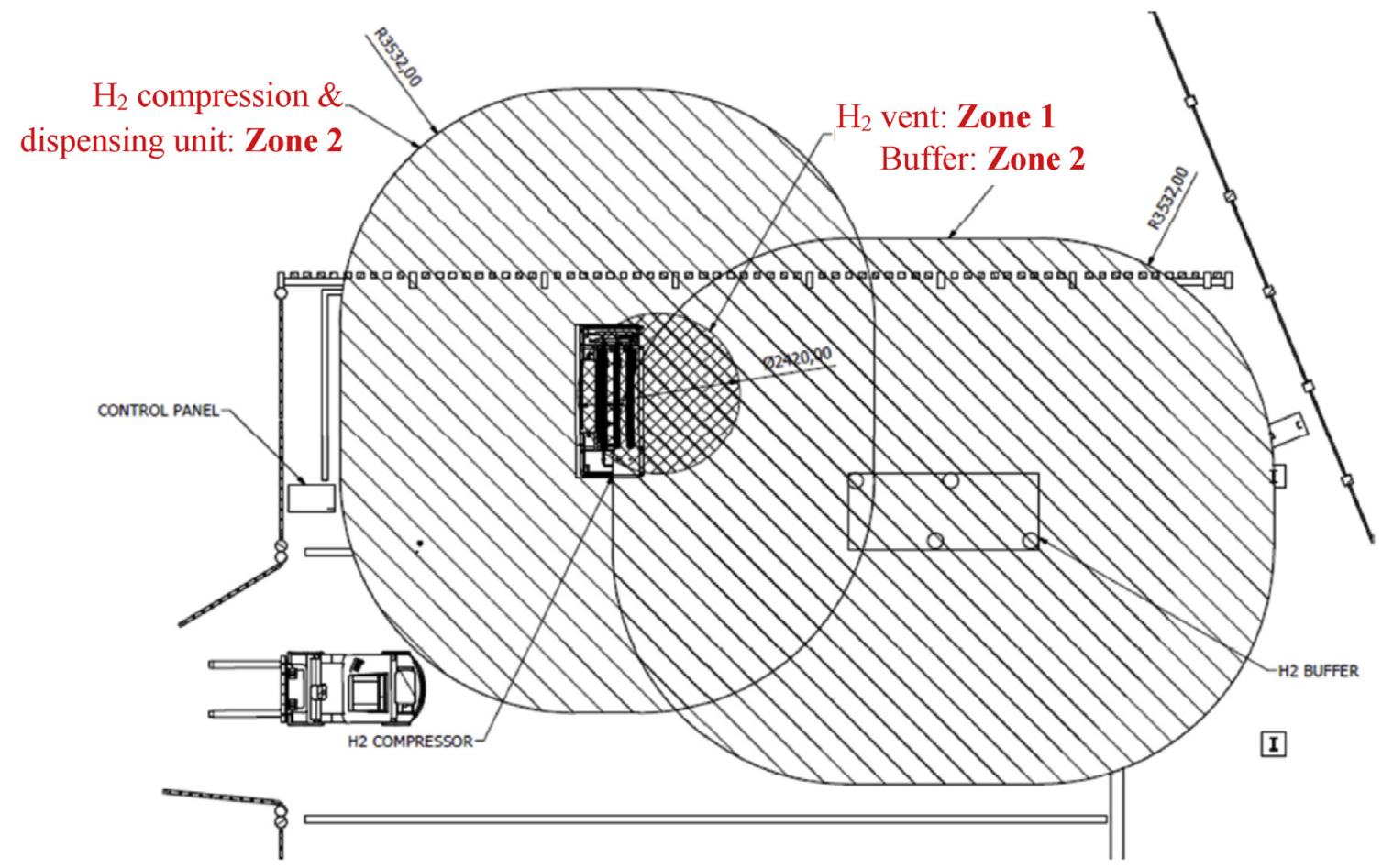

Fig. 11 - Site layout (top view). 


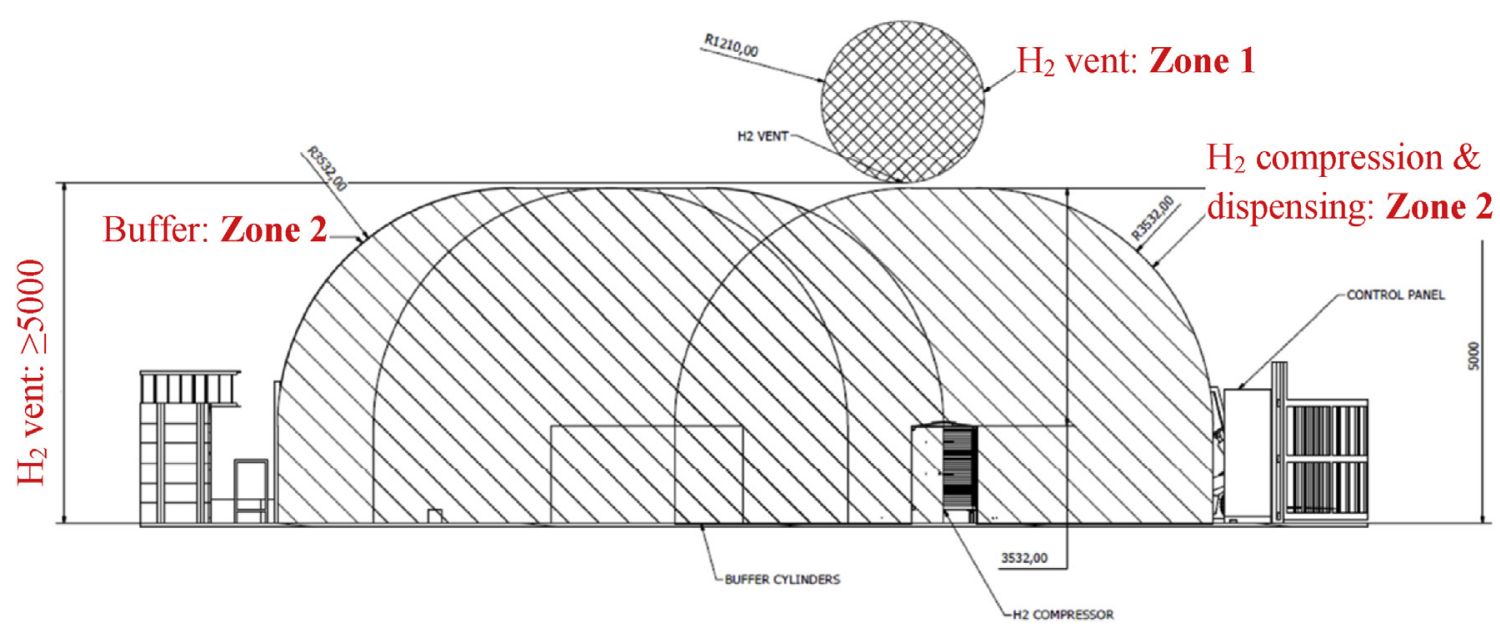

Fig. 12 - Site layout (side view).
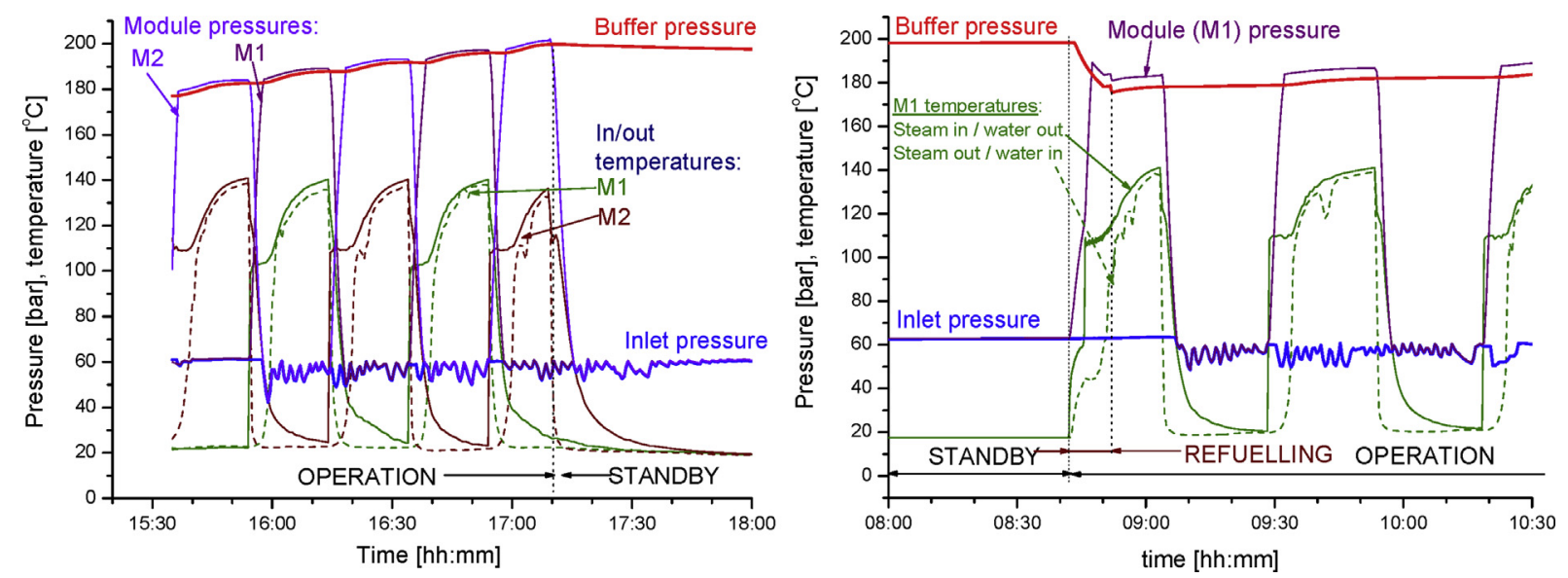

Fig. 13 - Typical operation of the hydrogen refuelling station. For the clarity, pressures and temperatures for the second compression module (M2) are not plotted on the right graph. The plots showing the temperatures of the compression modules are shown by solid and dashed lines for the top and bottom steam/water manifolds, respectively.

\section{Safety}

Although the refuelling station is an experimental prototype, it complies with South African safety regulations for the operation in fire-and-explosion hazardous environment $[16,17]$. For the determination of the hazardous zones, we also used the results of analysis of the relevant EU directives [18].

The zone classifications and sizes (Figs. 1, 11 and 12) can be considered as conservative due to the following factors:

- The station is an open air installation, and the wind speed of $0.5 \mathrm{~m} / \mathrm{s}$ is conservative.

- Hydrogen gas is 14.5 times lighter than air and thus has a high buoyancy. The released $\mathrm{H}_{2}$ will rise immediately, and the shape of the hazardous zone will rather form an upward plume than a sphere.

- The station was checked by professionals using hydrogen detecting devices before the plant was put into operation; the $\mathrm{H}_{2}$ leak tests are carried out periodically (every 3 months), as well as after each service work.

- The station is located in a locked environment with access control. The operating personnel is experienced with hydrogen gas and its related risks.

All electric parts used in the equipment located in the hazardous zone $\left(\mathrm{H}_{2}\right.$ compression and dispensing unit) are Exproof rated and additionally certified by South African safety authorities.

\section{On-site operation}

Details

The refuelling station was commissioned at Impala Platinum Refineries in September 2015 and officially launched in March 2016. 


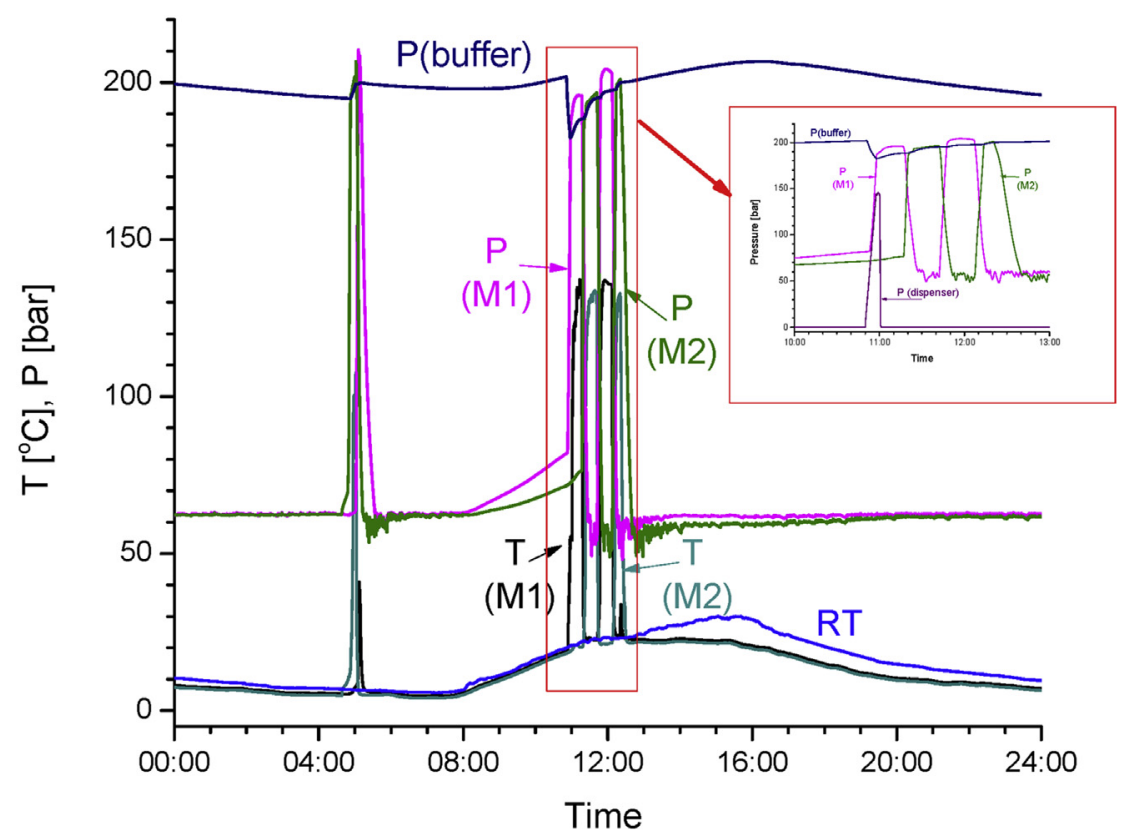

Fig. 14 - Typical daily operation of the refuelling station showing pressures $(P)$ and temperatures $(T)$ in the compression modules (M1, M2; the temperatures are plotted for the top manifolds), the pressures in the buffer and the output of the dispenser during refuelling (see inset), as well as the ambient temperature (RT).

Figs. 13 and 14 illustrate typical on-site operation of the station.

As it can be seen from Fig. 13, after beginning of the heating of a compression module, the temperatures in the top (steam inlet) and the bottom (condensate drain) manifolds equalise $\left(\mathrm{T}=100^{\circ} \mathrm{C}\right)$ in $5-6 \mathrm{~min}$ then gradually approaching $\sim 140^{\circ} \mathrm{C}$ by the end of the heating cycle (20 $\mathrm{min}$ ). The heating results in a fast (130 bar in $\sim 4 \mathrm{~min}$ ) increase of the $\mathrm{H}_{2}$ pressure in the gas manifold of the compression module; when the module pressure exceeds the pressure in the buffer at the output of the compressor, the compression module discharges high pressure $\mathrm{H}_{2}$ into the buffer. Since the modules $\mathrm{M} 1$ and $\mathrm{M} 2$ are working in the opposite phases, the buffer pressure continuously increases, with short ( $5 \mathrm{~min})$ interruptions in the periods between the end of heating of module M1 (M2) and beginning of heating of the opposite module M2 (M1).

After switching into the cooling mode, the temperatures of the bottom (water input) and top (water output) manifolds start to decrease immediately. The temperature at the input drops to its inlet value $\left(15-30^{\circ} \mathrm{C}\right.$ depending on the season and time) in $\sim 7$ min while water temperature at the output of the module decreases more slowly, with the difference
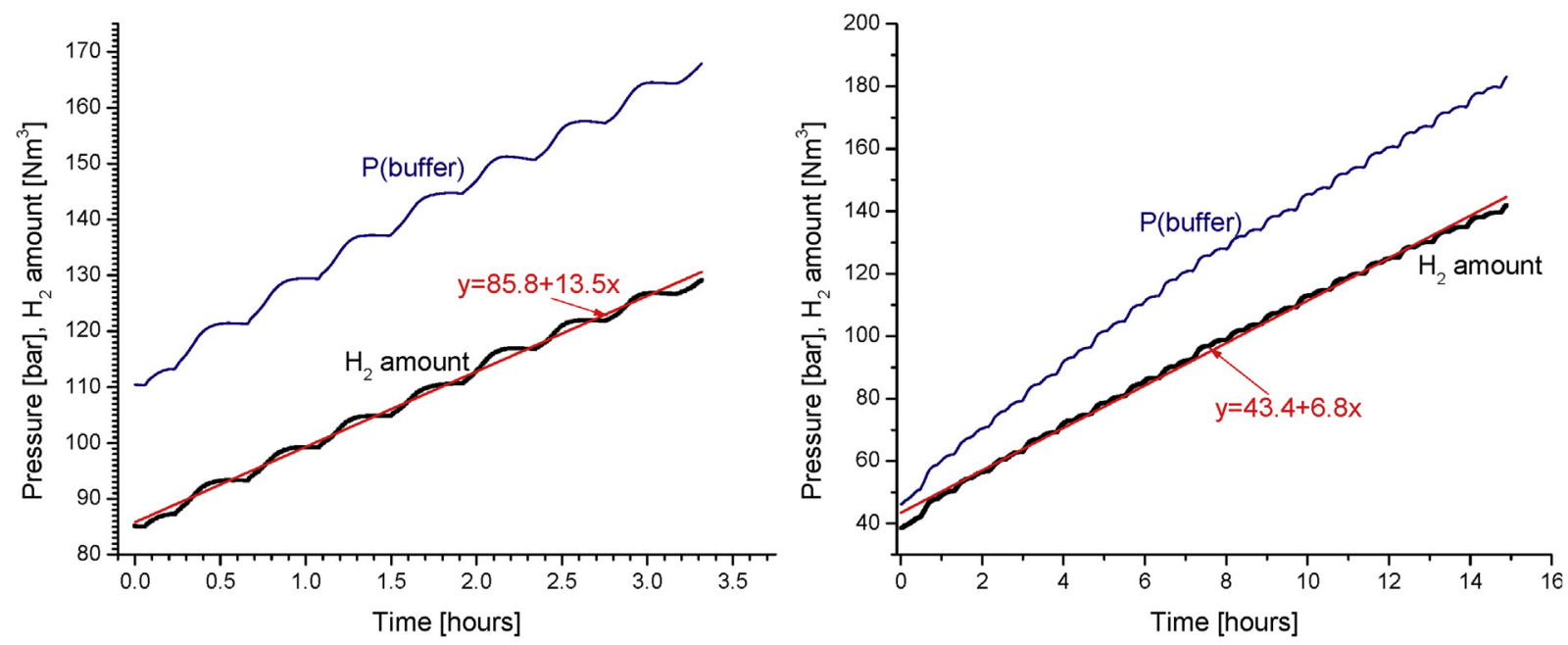

Fig. 15 - Operation of the MH compressor during the first (left; November 2015) and the third (right; December 2018) years of operation. 
( $\mathrm{T}_{\text {output }}-\mathrm{T}_{\text {input }}$ ) decreasing to $3-5{ }^{\circ} \mathrm{C}$ by the end of the cooling cycle $(20 \mathrm{~min})$. Nevertheless, the pressure in the cooled module quickly drops approaching $\mathrm{H}_{2}$ inlet pressure in 4-5 min when $\mathrm{T}_{\text {output }}$ decreases to $\sim 60^{\circ} \mathrm{C}$.

After the buffer pressure reaches 200 bar, the compressor is switched from the operation to the standby mode. In doing so, both modules are cooled down and all $\mathrm{MH}$ containers become almost completely charged with hydrogen. Due to that, when the operation of the compressor is activated again, the $\mathrm{H}_{2}$ compression productivity at the beginning is higher, and restoring the buffer pressure to $\mathrm{P}=200$ bar requires less than one full compression cycle when the buffer pressure decrease was caused by the decrease of the ambient temperature, or 2-4 full cycles after the refuelling (Fig. 14).

Fig. 15 (left) illustrates the operation of the $\mathrm{MH}$ compressor (time dependencies of the buffer pressure and amount of $\mathrm{H}_{2}$ in the buffer calculated using real gas equation) at the beginning of the operation (November 2015). Linear fit of the time dependence of the $\mathrm{H}_{2}$ amount in the buffer allowed to calculate the average compressor productivity to be of $13.5 \mathrm{Nm}^{3} / \mathrm{h}\left(28 \mathrm{~kg} \mathrm{H}_{2} /\right.$ day). Similar measurements taken after 36 months of the operation of the compressor (Fig. 15 (right)) showed about two-times drop in the productivity (to $6.8 \mathrm{Nm}^{3} / \mathrm{h}$ or $14.5 \mathrm{~kg} /$ day). It has to be noted that the pronounced drop of the productivity took place during the first 6 months of the operation, and thereafter the productivity was quite stable mostly varying between 5.5 and $7.2 \mathrm{Nm}^{3} / \mathrm{h}$.

The observed drop in the productivity of the $\mathrm{MH}$ compressor may have several origins including:

i. Degradation of the crystal structure of the intermetallic caused by the cycling and resulting in the drop of the reversible hydrogen storage capacity of the material at the operating conditions.

ii. Deterioration of hydrogen absorption/desorption kinetics caused by trace impurities of oxygen and water vapours in the feeding $\mathrm{H}_{2}$ which may be accumulated in the gas systems of the compressor.

iii. Malfunctions of the system components during prolonged operation.

We note that as distinct from the $\mathrm{AB}_{5}$-type alloys whose degradation behaviour during prolonged cycling is well studied (see, e.g. Ref. [10] and references therein), only several studies on cycling stability of the $\mathrm{AB}_{2}$-type intermetallics were published so far [19-27]. The recent studies [23-27] were mainly focused on the surface passivation effects in $\mathrm{AB}_{2}$-type hydrogen storage materials mainly related to their electrochemical applications [25-27], and only few works deal with cycling stability of the $\mathrm{AB}_{2}$-type $\mathrm{MH}$ materials in gas phase applications.

It was shown [21] that extended thermal cycling of $\mathrm{C} 14-\mathrm{AB}_{2}$ intermetallic in $\mathrm{H}_{2}$ (>85 000 cycles in the temperature range $45-120^{\circ} \mathrm{C}$ ) results in insignificant change of the PCT behaviour of the hydrogen storage material, and the loss of the reversible hydrogen storage capacity is below $10 \%$. The cycling does not result in a significant change of phase composition of the material except for the appearance of trace amount of a new phase identified in Ref. [21] as $\mathrm{Zr}$ and broadening XRD peaks of the $A B_{2}$ phase; the latter effect was also observed in Ref. [22]. Thus a contribution of degradation of the $A_{2}$-type material (factor i) in the drop of the $\mathrm{MH}$ compression productivity seems to be unlikely.

According to the information from Impala Platinum who consumes hydrogen which also feeds the MH compressor, its purity is above $99.99 \%$ with negligible concentration of critical impurities ( $\mathrm{CO}$ and $\mathrm{CO}_{2}$ less than $1 \mathrm{ppm}$ each, no sulphur). However, trace amounts of other impurities, first of all water vapours, may present in the feeding $\mathrm{H}_{2}$. As known from the literature $[23,24,28]$, the presence of water vapours in $\mathrm{H}_{2}$ may deteriorate hydrogen sorption performance of $\mathrm{AB}_{2}$ in a some extent. However, hydrogen sorption performance of the passivated material can be recovered by applying the regeneration procedure described above.

Indeed, the permanent operation of the compressor during every 5-6 months in 2017-2018 resulted in a gradual decrease of the productivity from $6.5-7.2$ to $5.5-6.2 \mathrm{Nm}^{3} / \mathrm{h}(\sim 15 \%)$, and after carrying out the regeneration, the productivity was completely restored. It allows us to conclude that the passivation of the $\mathrm{MH}$ material by the impurities in the feeding $\mathrm{H}_{2}$ (factor ii) contributes in the observed two-fold drop of the productivity only partially.

Apart from gradual decrease of the compressor's productivity mentioned above, two system malfunctions identified during the operation of the refuelling station resulted in a significant, down to $3 \mathrm{Nm}^{3} / \mathrm{h}$, drop of the productivity of the $\mathrm{H}_{2}$ compressor. These malfunctions included:

- Contamination of the pipelines with very fine powder of the $\mathrm{MH}$ material that resulted in $\mathrm{H}_{2}$ backflow through check valves 1.8, 1.9, 1.14, 1.15 (Fig. 3). ${ }^{2}$ The issue has been resolved by the installation of fine inline filters (F1, F2 in Fig. 3) in addition to $0.5 \mu \mathrm{m}$ grade filters attached to the $\mathrm{MH}$ containers;

- Malfunctions of the control system due to: (i) failures of electric components and (ii) errors of pressure sensors (1.4, 1.5 in Fig. 3) used for a feedback in the control of gas valves.

After fixing the above-mentioned failures in May 2017, the productivity of the compressor remained in the range 5.5-7.2 $\mathrm{Nm}^{3}$ without further drop, when the regeneration was carried out every 5-6 months.

Taking into account the above-mentioned, we believe that the major loss of the productivity was caused by malfunctions of the system components (factor iii). Most probably, the main origin was in a blocking of the $0.5 \mu \mathrm{m}$ grade sintered metal filters attached to the $\mathrm{MH}$ containers by a fine $\mathrm{MH}$ powder; the blocking could not be completely eliminated by the "backwash" with $\mathrm{H}_{2}$ during its absorption.

Certainly, the origin of the observed deterioration has to be investigated in more details; the corresponding studies related to both material and engineering issues are underway.

\footnotetext{
2 Initially, the pneumatically actuated valves $1.10-1.13$ were not installed; added at the later stage.
} 
Table 2 - Summary of the operation of the hydrogen refuelling station (September 2015-January 2019).

\begin{tabular}{lcc} 
Parameter & \multicolumn{2}{c}{ Value } \\
\cline { 2 - 3 } & Module 1 & Module 2 \\
\hline Operating hours of $\mathrm{H}_{2}$ compressor & 2410 & 1562 \\
Operating cycles & 5042 & 4557 \\
Regeneration hours & 20 & \\
Standby hours & 8241 & \\
Service hours & 40 & \\
Amount of $\mathrm{H}_{2}$ compressed $\left[\mathrm{Nm}^{3}\right]$ & 1173 \\
Amount of $\mathrm{H}_{2}$ dispensed $\left[\mathrm{Nm}^{3}\right]$ & 750 \\
Operation days logged & 530 \\
\hline Note: ${ }^{*}$ - during the time when $\mathrm{T}>60^{\circ} \mathrm{C}$. \\
\hline
\end{tabular}

\section{Summary}

Main parameters of the hydrogen refuelling station during its 38 month long on-site operation since commissioning in end September 2015 are summarised in Table 2.

It can be seen that during the logged period (530 full days), the refuelling station was mostly in the standby mode because of servicing only one fuel cell forklift which was used not very intensively and required refuelling only 1-2 times a week. Due to that, the decrease of the compressor productivity described above was not critical for the customer.

It also can be seen that the operation time of Module 1 of the compressor was $\sim 50 \%$ longer than for the Module 2 . It is explained by the operation algorithm when the switching of the compressor from the standby back to the operation mode starts from the heating of Module 1. In the future, the algorithm will be modified to allow more uniform workload distribution between the compression modules. Finally, the difference between amounts of the compressed and dispensed hydrogen has its origin in $\mathrm{H}_{2}$ venting from the buffer during the service works.

Despite some issues mentioned above, the prolonged operation has shown the feasibility of application of $\mathrm{MH} \mathrm{H}_{2}$ compression technology in medium-pressure (up to $200 \mathrm{bar}$ ) refuelling of the fuel cell forklifts. The ways to further optimise the system performance towards increase of reliability, productivity and efficiency include (i) identifying the origin of the decrease of the productivity during prolonged operation and minimizing this effect by the corresponding material and engineering solutions; (ii) further improvement of the design of the $\mathrm{MH}$ container and its accessories, to reduce heat losses during its thermal cycling and to eliminate contamination of the released $\mathrm{H}_{2}$ with fine $\mathrm{MH}$ powder; (iii) further optimisation of heating/cooling circuits in the system with possible introduction of the heat recovery option [29]; (iv) further optimisation of the operation parameters including the algorithms of switching between the standby and operation modes, process setpoints, etc.

\section{Economic estimations}

Fig. 16 presents breakdown of the direct costs (without labour) incurred by HySA Systems for the making and installation of the hydrogen refuelling station. The total costs accounted 1.94 million South African Rand that was equivalent to USD 140 thousand (the rate on September 30, 2015 [30]).

The main part of the costs $(28 \%)$ relates to the design, making and assembling of the parts of the refuelling station. $25 \%$ of the total costs were spent for the making main components of the $\mathrm{MH}$ compressor including $\mathrm{MH}$ material $\left(\sim^{1 / 4}\right)$ and $\mathrm{MH}$ containers (the balance).

The annual operation costs of the refuelling station were estimated as 100 thousand South African Rand (about USD 7 thousand; the rate for December 2017). We note that these costs mainly incurred for the service and upgrade of the prototype to eliminate its defects which can be identified only during prolonged operation, will be significantly lower in the future when the defects will be eliminated already at the design stage.

As it can be seen, even for the prototype, both capital and operation costs are significantly lower than for the standard 350-700 bar hydrogen refuelling stations available on the market (see Introduction). These benefits are due to: (i) lower $\mathrm{H}_{2}$ dispensing pressure which enables the use of standard gas service components; (ii) slow pressure ramping which prevents overheating of the supplied $\mathrm{H}_{2}$ and, thus, eliminates the requirement for deep cooling; (iii) the replacement of a mechanical $\mathrm{H}_{2}$ compressor with the $\mathrm{MH}$ one.

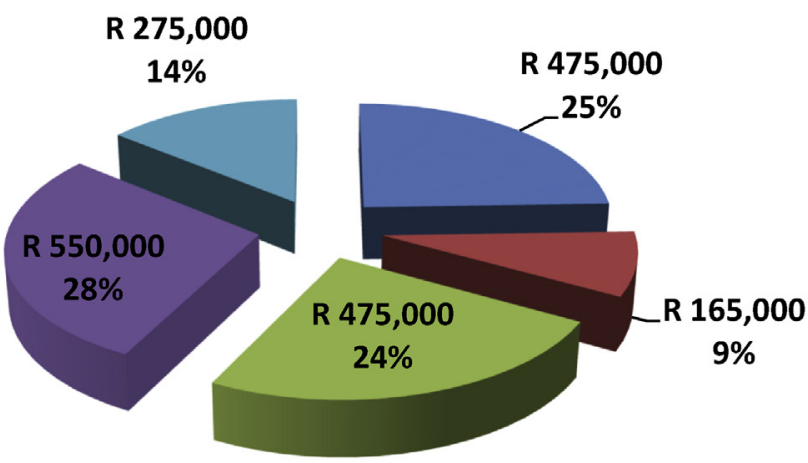

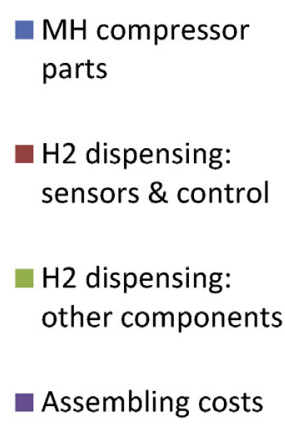

Other costs

Fig. 16 - Breakdown of the incurred costs (in South African Rand, 2015) for the making and installation of the hydrogen refuelling station. 


\section{Conclusions}

In this work, we reported about features and experience of 38 month-long uninterrupted operation in the industrial environment of a prototype medium-pressure (dispensing at 185 bar) hydrogen refuelling station with integrated 50-200 bar metal hydride hydrogen compressor which utilises services available at the customer's site.

The station is characterised by simplicity in design, operation and service, high safety and reliability, noiseless operation, and lower capital and operating costs than highpressure (350-700 bar) hydrogen refuelling stations available on the market.

Despite a number of issues mainly resulting in the decrease of the productivity of the metal hydride compressor, the on-site operation has shown the feasibility of application of the metal hydride hydrogen compression technology in the medium-pressure refuelling of fuel cell forklifts. We have demonstrated several ways to further optimise the system performance towards increase of reliability, productivity and efficiency.

\section{Acknowledgements}

This work is funded by the Department of Science and Technology within the HySA Programme (HySA Systems projects KP3-S02, KP6-S02 and KP6-S03), and Impala Platinum Limited; South Africa. In 2013-2015, the investment from the industrial funder was leveraged through the Technology and Human Resources for Industry Programme, jointly managed by the South African National Research Foundation (NRF) and the Department of Trade and Industry; THRIP Project TP1207254249). Since end 2017, the international collaboration activities within this work are supported by the EU Horizon 2020 program; Grant Agreement 778307 - HYDRIDE4MOBILITY - H2020-MSCA-RISE-2017.

ML and MWD also acknowledge NRF support, grant numbers 109092 (ML) and 116278 (MWD).

\section{R E F E R E N C E S}

[1] Reddi K, Elgowainy A, Rustagi N, Gupta E. Impact of hydrogen refueling configurations and market parameters on the refueling cost of hydrogen. Int J Hydrogen Energy 2017;42:21855-65.

[2] Elgowainy A, Reddi K, Lee D-Y, Rustagi N, Gupta E. Technoeconomic and thermodynamic analysis of pre-cooling systems at gaseous hydrogen refuelling stations. Int J Hydrogen Energy 2017;42:29067-79.

[3] Blazquez-Diaz C. Techno-economic modelling and analysis of hydrogen fuelling stations. Int J Hydrogen Energy 2019;44:495-510.

[4] Weinert JX, Shaojun L, Ogdena M, Jianxin M. Hydrogen refueling station costs in Shanghai. Int J Hydrogen Energy 2007;32:4089-100.
[5] Johnson T, Mallow A, Bowman R, Smith B, Anovitz L, Jensen C. Metal hydride compression, US DoE hydrogen and fuel cells program, project ID PD138. 28 March 2018. https:// www.hydrogen.energy.gov/pdfs/review18/pd138_johnson 2018_o.pdf.

[6] Jensen JO, Vestb $\varnothing$ AP, Li Q, Bjerrum NJ. The energy efficiency of onboard hydrogen storage. J Alloy Comp 2007:446-447:723-8.

[7] Lototskyy MV, Yartys VA, Pollet BG, Bowman Jr RC. Metal hydride hydrogen compressors: a review. Int J Hydrogen Energy 2014;39:5818-51.

[8] Yartys VA, Lototskyy M, Linkov V, Grant D, Stuart A, Eriksen J, Denys R, Bowman Jr RC. Metal hydride hydrogen compression: recent advances and future prospects. Appl Phys A 2016;122:415. https://doi.org/10.1007/s00339-016-9863-7.

[9] Lototskyy M, Klochko Y, Davids MW, Pickering L, Swanepoel D, Louw G, van der Westhuizen B, Chidziva S, Sita C, Bladergroen B, Linkov V. Industrial-scale metal hydride hydrogen compressors developed at the South African Institute for Advanced Materials Chemistry. Mater Today: Proc 2018;5:10514-23.

[10] Tarasov BP, Bocharnikov MS, Yanenko YB, Fursikov PV, Lototskyy MV. Cycling stability of $\mathrm{RNi}_{5}(\mathrm{R}=\mathrm{La}, \mathrm{La}+\mathrm{Ce})$ hydrides during the operation of metal hydride hydrogen compressor. Int J Hydrogen Energy 2018;43:4415-27.

[11] Suermann M, Kiupel T, Schmidt TJ, Büchi FN. Electrochemical hydrogen compression: efficient pressurization concept derived from an energetic evaluation. J Electrochem Soc 2017;164:F1187-95.

[12] Lototskyy MV, Tolj I, Davids MW, Klochko YV, Parsons A, Swanepoel D, Ehlers R, Louw G, van der Westhuizen B, Smith F, Pollet BG, Sita C, Linkov V. Metal hydride hydrogen storage and supply systems for electric forklift with lowtemperature proton exchange membrane fuel cell power module. Int J Hydrogen Energy 2016;41:13831-42.

[13] Lototskyy MV, Tolj I, Parsons A, Smith F, Sita C, Linkov V. Performance of electric forklift with low-temperature polymer exchange membrane fuel cell power module and metal hydride hydrogen storage extension tank. J Power Sources 2016;316:239-50.

[14] Pickering L, Lototskyy MV, Davids MW, Sita C, Linkov V. Induction melted $\mathrm{AB}_{2}$-type metal hydrides for hydrogen storage and compression applications. Mater Today: Proc 2018;5:10470-8.

[15] Lototskyy M, Davids MW, Pollet BG, Linkov V, Klochko Y. Metal hydride bed, metal hydride container, and method for the making thereof, Patent application WO. 2015. 189758 A1.

[16] SANS 60079-10-1. IEC 60079-10-1:2008, South African national standard, "explosive atmospheres - Part 10-1: classification of areas - explosive gas atmospheres". 2010. https://store.sabs.co.za/catalog/product/view/_ignore_ category/1/id/225608/s/sans-60079-10-1-2010-ed-1-00/.

[17] SANS 10108. South African National Standard, "The classification of hazardous locations and the selection of apparatus for use in such locations". Ed 6 2014.. https://store. sabs.co.za/catalog/product/view/_ignore_category/1/id/ 218015/s/sans-10108-ed-6-00/.

[18] Nilsen S, Marangon A, Middha P, Engeboe A, Markert F, Ezponda E, Chaineaux J. Determination of Hazardous Zones for a Generic Hydrogen Station - A Case Study; https://www. researchgate.net/publication/281992185_Determination_of_ hazardous_zones_for_a_generic_hydrogen_station_A_case_ study.

[19] Wanner M, Friedlmeier G, Hoffmann G, Groll M. Thermodynamic and structural changes of various 
intermetallic compounds during extended cycling in closed systems. J Alloy Comp 1997;253-254:692-7.

[20] Ulmer U, Dieterich M, Pohl A, Dittmeyer R, Linder M, Fichtner M. Study of the structural, thermodynamic and cyclic effects of vanadium and titanium substitution in laves-phase $\mathrm{AB}_{2}$ hydrogen storage alloys. Int J Hydrogen Energy 2017;42:20103-10.

[21] Wanner M, Hoffmann G, Groll M. Thermodynamic and structural changes of an $\mathrm{AB}_{2}$-Laves-Phase alloy $\left(\mathrm{Ti}_{0.98} \mathrm{Zr}_{0.02} \mathrm{~V}_{0.43} \mathrm{Fe}_{0.06} \mathrm{Cr}_{0.05} \mathrm{Mn}_{1.52}\right)$ during extended thermal cycling. In: Saetre TO, editor. Hydrogen power: theoretical and engineering solutions. Dordrecht: Springer; 1998. p. 257-62. https://doi.org/10.1007/978-94-015-9054-9_33.

[22] Iosub V, Joubert J-M, Latroche M, Cerný R, PercheronGuégan A. Hydrogen cycling induced diffraction peak broadening in C14 and C15 Laves phases. J Solid State Chem 2005;178:1799-806.

[23] Maeda T, Fuura T, Matsumoto I, Kawakami Y, Masuda M. Cyclic stability test of $\mathrm{AB}_{2}$ type $(\mathrm{Ti}, \mathrm{Zr})(\mathrm{Ni}, \mathrm{Mn}, \mathrm{V}, \mathrm{Fe})_{2.18}$ for stationary hydrogen storage in water contaminated hydrogen. J Alloy Comp 2013;580:S255-8.
[24] Zhang T, Wu T, Xue X, Hu R, Kou H, Li J. Hydrogen storage performance of a pseudo-binary Zr-V-Ni Laves phase alloy against gaseous impurities. Renew Energy 2017;103:786-93.

[25] Park HY, Cho WI, Cho BW, Lee SR, Yun KS. Effect of fluorination on the lanthanum-doped $\mathrm{AB}_{2}$-type metal hydride electrodes. J Power Sources 2001;92:149-56.

[26] Young K, Wong DF, Yasuoka S, Ishida J, Nei J, Koch J. Different failure modes for $\mathrm{V}$-containing and $\mathrm{V}$-free $\mathrm{AB}_{2}$ metal hydride alloys. J Power Sources 2014;251:170-7.

[27] Young K, Ouchi T, Fetcenko MA. Pressure-composition-temperature hysteresis in C14 Laves phase alloys: Part 1. Simple ternary alloys. J Alloy Comp 2009;480:428-33.

[28] Sandrock G. A panoramic overview of hydrogen storage alloys from a gas reaction point of view. J Alloy Comp 1999;293-295:877-88.

[29] Lototskyy M, Klochko Y, Linkov V, Lawrie P, Pollet BG. Thermally driven metal hydride hydrogen compressor for medium-scale applications. Energy Procedia 2012;29:347-56.

[30] Current and Historical Rate Tables; https://www.xe.com/. 